ECOLOGICA, Vol. 28, No 102 (2021), 271-276

https://doi.org/10.18485/ecologica.2021.28.102.19

Originalni naučni rad

UDC: 338.48-44(1-87):[616.98:578.834]

\title{
Negativan uticaj pandemije COVID-19 na međunarodni turizam
}

\section{Negative effects of the Covid-19 pandemic on international tourism}

\author{
Nikola Bošković ${ }^{1 *}$, Danijela Despotović ${ }^{2}$, Lela Ristić ${ }^{3}$ \\ 1,2,3Univerzitet u Kragujevcu, Ekonomski fakultet, Liceja Kneževine Srbije 3, 34000 Kragujevac, Srbija \\ University of Kragujevac, Faculty of Economics, Liceja Kneževine Srbije 3, 34000 Kragujevac, Serbia \\ *Autor za prepisku / Corresponding author
}

Rad primljen / Received: 09.02.2020, Rad prihvaćen / Accepted: 15.05.2021.

Sažetak: Turizam predstavlja jednu od najbrže rastućih privrednih grana tokom XXI veka na globalnom niovu. Razvoj turizma umnogome prati sveukupan ekonomski i društveni razvoj i po pravilu zavisi od brojnih faktora koji su izvan njegove direktne kontrole. To se naročito odnosi na međunarodni turizam, koji pokazuje veliku osetjivost na promene na međunarodnom tržištu, koje mogu biti rezultat ekonomskih i neekonomskih turbulencija. Tokom 2020.godine, usled pandemije COVID-19, u najvećem broju zemalja uvedena su brojna ograničenja u pogledu kretanja ljudi, koja su dovela do značajnog pada međunarodnog turizma.

U ovom radu je dat pregled efekata pandemije COVID-19 na rezultate međunarodnog turizma u 2020.godini u odnosu na prethodni period. Rezultati istraživanja pokazuju dramatičan pad kretanja turista od $73,9 \%$ na globalnom nivou, što je dovelo do brojnih negativnih efekata međunarodnog turizma po mnoge nacionalne ekonomije. Doprinos rada se ogleda u pokušaju davanja konkretnih predloga za ublažavanje ovakvih negativnih tendencija po turizam jedne zemlje, koji se može delimično otkloniti stimulisanjem razvoja domaćeg turizma.

Ključne reči: međunarodni turizam, COVID-19, razvoj.

\begin{abstract}
At a global level, tourism is one of the fastest growing industries in the twenty-first century. The development of tourism is mainly followed by overall economic and social progress, and as a rule depends on numerous factors beyond its direct control. This especially refers to international tourism, which shows great sensitivity to changes on the international market and can be a result of economic and non-economic turbulences. In 2020, due to the COVID 19 pandemics, numerous limitations were imposed related to people's mobility which led to significant decline in international tourism.

This paper provides a review of effects of the COVID 19 pandemics in 2020 in comparison to the previous period. The results of research show dramatic decrease of tourists' mobility, amounting $73.9 \%$ on a global level, which led to numerous negative effects of international tourism on many national economies. The contribution of the paper includes suggestions for decrease of such negative impacts on tourism of a country, which can be partly eliminated by stimulating the development of domestic tourism.
\end{abstract}

Keywords: international tourism, COVID 19, development.

\footnotetext{
10rcid.org/ 0000-0003-2105-6196, e-mail: nikolab@kg.ac.rs

2orcid.org/ 0000-0002-2610-8605, e-mail: ddespotovic@kg.ac.rs

${ }^{3}$ orcid.org/ 0000-0002-4590-8261, e-mail: Iristic@kg.ac.rs
} 


\section{UVOD / INTRODUCTION}

Za dve decenije XXI veka svet se s epidemijama i pandemijama zaraznih bolesti susreo više puta, i to: SARS - 2003; ptičji grip H5N1 - 2005; svinjski grip H1N1 - 2009; bliskoistočni respiratorni sindrom MERS - 2012; ZIKA virus - 2015 i COVID-19, izazvan SARS-2 korona virusom - 2019.godine (Đurović et al., 2020). Najveće negativne efekte je izazvao poslednji navedeni virus, koji je dobio globalne razmere tokom 2020.godine i još uvek se ne vidi i ne nazire njegov kraj. Koronavirus je virus koji izaziva akutne respiratorne sindrome (SARS- severe acute respiratory sindrom) i uglavnom se prenosi sa životinja na čoveka (Uğur et al., 2020). On se pojavio u Kini krajem 2019.godine, da bi se početkom 2020.godine proširio na ostali deo sveta, pre svega na zemlje EU i SAD u prvoj polovini godine, da bi u drugoj polovini 2020.godine postao intenzivniji na području južne hemisfere. Pandemija COVID-19 je proglašena 11.03.2020.godine od strane Svetske Zdravstvene Organizacije. Od tada pa do današnjih dana, sa neizvesnim predviđanjima u narednim periodima, ona je postala glavni „kreator” svih tokova na globalnom niovu.

Odgovor najvećeg broja država je bio u sprovođenju različitog vida karantina, koji je ostavio brojne posledice po ekonomiju (Vassileva et al., 2020). Već u martu 2020. godine neki vid karantina je bio pristutan u zemljama gde je živelo preko $90 \%$ svetskog stanovništva (Gössling et al., 2020). Taj procenat se do kraja godine uvećao, tako da je pored karantina, prisutna i velika neizvesnost, nepredvidivost, što je dovelo do brojnih negativnih efekata po mnoge ekonomije. Najveći gubitnici tokom 2020. godine su uslužne delatnosti, koje su svoje aktivnosti značajno umanjile zbog smanjene tražnje izazvane brojnim restriktvnim merama. Tu se pre svega misli na one uslužne sektore, koji su podrazumevali kretanje ljudi iz jedne zemlje u drugu. Najveće negativne efekte 2020.godine su osetile avio industrija i turizam.

I pored nesumnjivog negativnog uticaja pandemije COVID-19 na ljudsku populaciju, prvenstveno zbog broja preminulih i zaraženih, a taakođe i zbog razarajućeg efekta na ekonomije širom sveta, pandemija je imala i određene pozitivne efekte. Pružila nam je mnoge pouzdane dokaze o negativnim efektima aktivnosti čoveka na životnu sredinu. lako oni neće dovesti do kraja sporenja o uticaju ljudskih aktivnosti na klimatske promene, nesumnjivo su dokazani uticaji čoveka na zagađenje vode, vazduha i tla (Lukinović, Jovanović, 2020).

$\mathrm{U}$ prilog tome govore i podaci da se vrednost ekološkog otiska, koji pokazuje uticaj čoveka na ekološki sistem, smanjila tokom 2020.godine i vratila na nivo od pre 10 godina. Upravo je to posledica $u$ najvećoj meri značajnog smanjenja aviosaobraćaja, kao jednog od najvećih zagađivača vazduha, a samim tim i životne sredine u celini.

Takođe, usled ograničenja fizičkog kretanja ljudi, došlo je do intenziviranja razvoja brojnih oblika etrgovine, koja je postala prisutna kod sve većeg broja stanovnika, ali i u sve većem broju zemalja. To je intenziviralo i razvoj drugih aspekata masovnijeg porasta korišenja informacionih tehnologija i razvoja digitalne ekonomije.

Iz svega izloženog, pandemija COVID-19 je ostavila i ostaviće i u narednom periodu dominantno negativne efekte po ljudsko društvo. Kao što je već istaknuto, jedan od ključnih negativnih efekata je po razvoj turizma, i to naročito razvoj međunarodnog turizma. Shodno tome, predmet analize ovog rada je uticaj pandemije COVID-19 na razvoj međunarodnog turizma. Rad se sastoji iz tri segmenta: razvoj međunarodnog turizma, kako na globalnom nivou, tako i na području Republike Srbije do pojave pandemije, efekata pandemije po međunarodni turizam na globalnom nivou i efekata pandemije na području Republike Srbije..

\section{RAZVOJ MEĐUNARODNOG TURIZMA U PERIODU PRE PANDEMIJE COVID-19 / DEVELOPMENT OF INTERNATIONAL TOURISM IN THE PERIOD BEFORE THE COVID-19 PANDEMIC}

Turizam je aktivnost koja podrazumeva kretanje i boravak turista u mestima koja nisu mesta njihovog stalnog boravka (Milenković, Bošković, 2014). On je rezultat, pre svega, opšteg ekonomskog i društvenog napretka, koji se odigrao na globalnom nivou u poslednjih nekoliko decenija. Porast životnog standarda uslovio je i povećanje diskrecionog dohotka sve većeg broja ljudi na Planeti, što je, uz smanjenje trajanja radne nedelje, dovelo do mogućnosti realizovanja turističkih želja i motiva kod velikog broja ljudi (Page, Connell, 2020).

Ekonomski efekti razvoja turizma u poslednje dve decenije doveli su do njegove dominacije na globalnom nivou, gde se on profilisao kao jedna od vodećih razvojnih privrednih grana mnogih nacionalnih ekonomija (Kostić et al., 2018). U prilog tome govore sledeći pokazatelji turizma (UNWTO, 2020):

1. učestvuje u stvaranju $10,3 \%$ globalnog GDP-a ili u apsolutnom iznosu sa oko 8.900 mlrd \$;

2. učestvuje u svetskoj zaposlenosti sa oko 330 miliona ili 10\%, i

3. ostvaruje izvoz od 1.600 mlrd $\$$ godišnje, što predstavlja 6,5\% izvoza svih roba i usluga, odnosno $27,2 \%$ izvoza sektora usluga. 
Razvoj turizma, naročito njegova međunarodna komponenta, je prepoznata od strane velikog broja zemalja, kao poželjno sredstvo ekonomskog razvoja. U prilog tome govore globalni podaci o kretanju međunarodnih turista i efekata koje oni stvaraju. Ti efekti su najpre prepoznati kao priliv deviznih sredstava, poboljšanje platnog bilansa, porast zaposlenosti, porast dohotka, kao i brojni direktni i indirektni doprinosi lokalnoj ekonomiji (Stefanović, Gligorijević, 2016). Kao rezultat prvobitno uočenih i evidentiranih efekata, a prateći kretanja na globalnom turističkom tržištu, turizam je bio favorizovaniji i prihvatljiviji od drugih privrednih grana u mnogim nacionalnim ekonomijama, jer: turizam je, istorijski posmatrano, i biće, rastuća industrija; najveći deo investicija u međunarodni turizam dolazi iz bogatijih, ekonomski razvijenih zemalja; međunarodni turizam omogućava priliv stranog novca; turizam je tipično radno intenzivni sektor; turizam ne podleže trgovinskim ograničenjima i ostalim restrikcijama međunarodnog tržišta; veliki broj atrakcija (npr. klimatske, kulturne, atrakcije okruženja) su „besplatne“, i turizam osnažuje ekspanziju drugih sektora lokalne ekonomije (Bošković, 2020).

$\mathrm{U}$ narednoj tabeli prikazano je kretanje broja međunarodnih turističkih dolazaka i broja ostvarenih noćenja od međunarodnog turizma u periodu nakon 2010.godine.

Tabela 1 - Osnovni parametri razvoja međunarodnog turizma u periodu 2010-2019.godina

Table 1 - Basic parameters of international tourism development in period 2010-2019

\begin{tabular}{|c|c|c|c|c|}
\hline & \multicolumn{2}{|c|}{ Turistički dolasci } & \multicolumn{2}{c|}{ Turistička prihodi } \\
\hline & $\begin{array}{c}\text { Ukupan broj, u } \\
\text { milionima }\end{array}$ & $\begin{array}{c}\text { Indeks rasta } \\
2010=100\end{array}$ & $\begin{array}{c}\text { Ukupan broj, } \\
\text { u milijardama \$ }\end{array}$ & $\begin{array}{c}\text { Indeks rasta } \\
2010=100\end{array}$ \\
\hline 2010 & 956 & 100 & 981 & 100 \\
\hline 2013 & 1.100 & 115 & 1.222 & 125 \\
\hline 2015 & 1.203 & 126 & 1.226 & 125 \\
\hline 2017 & 1.332 & 139 & 1.350 & 138 \\
\hline 2019 & 1.454 & 152 & 1.494 & 152 \\
\hline
\end{tabular}

Izvor: Autori prema UNWTO, 2021a

Iz prezentirane tabele zaključujemo da je broj međunarodnih turističkih dolazaka u analiziranom periodu (2010-2019.godina) uvećan za gotovo 500 miliona, odnosno, porastao je sa 956 miliona na milijardu i 454 miliona. Slične tendencije ostvaruje i kretanje prihoda od međunarodnog turizma, koji je u analiziranom periodu uvećan za preko 500 milijardi \$, odnosno sa 981 na 1.494 milijardi \$.
Ukoliko posmatramo Republiku Srbiju u periodu 2010-2019.godina i efekat koji nastaje od međunarodnog turizma, možemo generalno istaći da je ona značajno poboljšala svoj položaj na međunarodnom turističkom tržištu, o čemu govore podaci prezentirani u tabeli 2.

Tabela 2 - Osnovni parametri razvoja međunarodnog turizma na području Republike Srbije, u periodu 2010-2019.godina

Table 2 - Basic parameters of international tourism development in Republic of Serbia in period 20102019

\begin{tabular}{|c|c|c|c|c|}
\hline & \multicolumn{2}{|c|}{ Turistički dolasci } & \multicolumn{2}{c|}{ Turistički prihodi } \\
\hline & $\begin{array}{c}\text { Ukupan broj, } \mathrm{u} \\
\text { hiljadama }\end{array}$ & $\begin{array}{c}\text { Indeks rasta } \\
2010=100\end{array}$ & $\begin{array}{c}\text { Ukupan broj, } \\
\text { u milionima } €\end{array}$ & $\begin{array}{c}\text { Indeks rasta } \\
2010=100\end{array}$ \\
\hline 2010 & 764 & 100 & 605 & 100 \\
\hline 2013 & 922 & 121 & 792 & 131 \\
\hline 2015 & 1.132 & 148 & 945 & 156 \\
\hline 2017 & 1.497 & 196 & 1.178 & 195 \\
\hline 2019 & 1.864 & 244 & 1.436 & 237 \\
\hline
\end{tabular}

Izvor: Autori prema UNWTO, 2021a i NBS, 2021 
U posmatranom periodu, broj turističkih dolazaka je uvećan 2,44 puta (144\%), što značajno prevazilazi prosečan globalni rast od $52 \%$, koji je predstavljen u tabeli 1 . Slične tendencije pokazuje i rast turističkih prihoda od međunarodnog turizma. Ovako dobre, iznad prosečne rezultate u poslednjih 10 godina (kada je beležena prosečna godišnja stopa rasta od $10 \%$ ), a naročito u periodu 2015 2019. godina, međunarodni turizam u Republici Srbiji je ostvario pre svega zahvaljujući dobrim merama ekonomske politike u smislu stimulisanja privlačenja stranih turista, ali i formiranju kvalitetnijih turističkih proizvoda.

\section{EFEKAT PANDEMIJE COVID-19 NA GLOBALNI MEĐUNARODNI TURIZAM / THE EFFECT OF THE COVID-19 PANDEMIC ON GLOBAL INTERNATIONAL TOURISM}

Pandemija COVID-19 dovela do značajnih promena u međunarodnom turizmu. Te promene su izazvane u najvećem broju slučajeva merama zemalja u vidu ograničenja kretanja ljudi, a ne kao rezultat smanjenja želje turista za putovanjem. Takođe, finansijski aspekt nije evidentiran kao razlog smanjenja među- narodnih turističkih putovanja. Različiti vidovi ograničenja, od delimičnog do potpunog zaključavanja, doveli su do pada broja međunarodnih turističkih dolazaka 2020.godine na 379 miliona u odnosu na 1.454 miliona prethodne 2019. godine (Grafikon 1). Pad od $73,9 \%$ je međunarodni turizam „vratio” decenijama unazad (1988. godine ukupan broj međunarodnih turističkih dolazaka je bio 384 miliona).

Posebno je ilustrativan mesečni pad broja turističkih dolazaka, koji je u periodu april-maj 2020. godine iznosio preko $96 \%$ u odnosu na isti period prethodne godine, kao i oktobar-decembar, kada je zabeležen pad od preko 80\% (Grafikon 2).

Ovakve tendencije međunarodnog turizma značajno su umanjile efekat koji je turizam imao u prethodnim decenijama po razvoj mnogih ekonomija. Prema preliminarnim podacima Svetske turističke organizacije (UNWTO), direktan gubitak od međunarodnog turizma 2020. godine iznosio je oko 1.300 milijardi \$, što je preko 11 puta veći gubitak nego u vreme svetske ekonomske krize 2009. godine (UNWTO, 2021b).

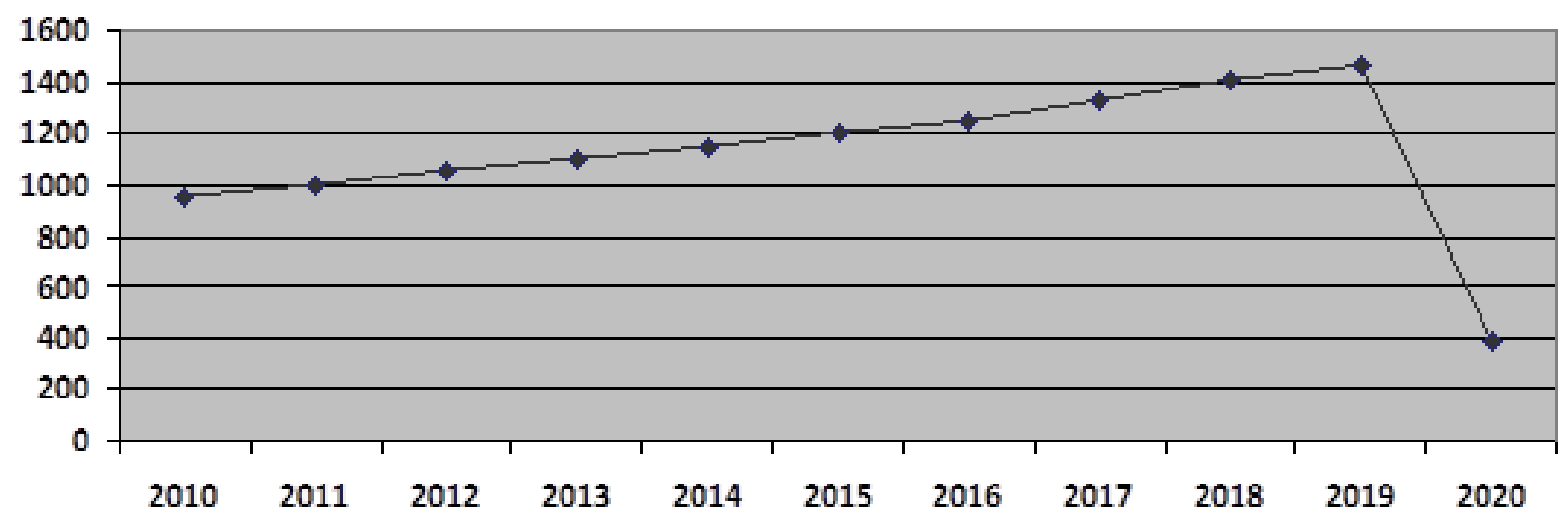

Grafikon 1 - Broj međunarodnih turističkih dolazaka u periodu 2010-2020.godina, u milionima Graph 1 - Number of international tourist arrivals in the period 2010-2020, in millions Izvor: Autori prema UNWTO, 2021a
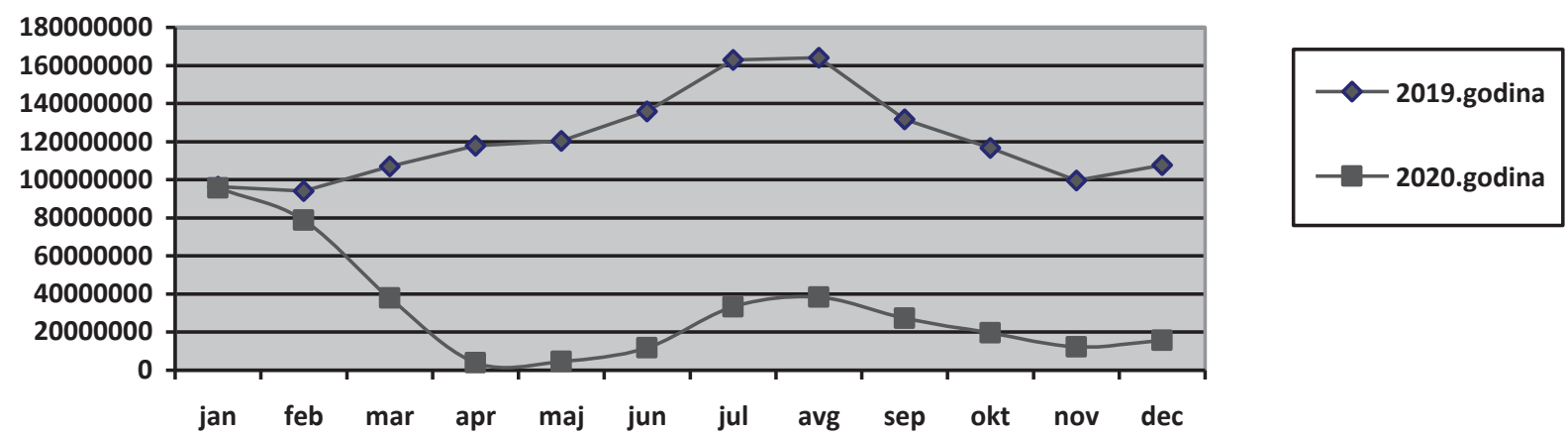

Grafikon 2 - Broj međunarodnih turističkih dolazaka tokom 2019. i 2020.godine, po mesecima Graph 2 - Number of international tourist arrivals during 2019 and 2020, by month Izvor: Autori prema UNWTO, 2021a 
3. EFEKAT PANDEMIJE COVID-19 NA MEĐUNARODNI TURIZAM U REPUBLICI SRBIJI / EFFECT OF THE COVID-19 PANDEMIC ON INTERNATIONAL TOURISM IN THE REPUBLIC OF SERBIA

Pandemija COVID-19 je tokom 2020. godine uticala u velikoj meri i na rezultate međunarodnog turizma na području Republike Srbije. Na Grafikonu 3 je jasno prikazano da je u posmatranoj godini došlo do značajnog pada broja međunarodnih turističkih dolazaka u odnosnu na prethodnu godinu, sa 1.846.551 na 445.711, što predstavlja pad od $75,9 \%$, što je iznad globalnog pada $(73,9 \%)$.
Ono što je posebno indikativno za međunarodni turizam na području Republike Srbije predstavlja činjenica da je najveći procentualni pad broja međunarodnih dolazaka ostvaren u regionu Beograd $79,3 \%$. To je rezultat dominantne uloge razvoja gradskog turizma, dok ostali regioni (Vojvodina, Šumadija i Zapadna Srbija i Južna i Istočna Srbija) beleže procentualno nešto manji pad $(74 \%, 71,4 \%$ i $72,5 \%$ respektivno), zbog planinskog i banjskog turizma, koji su najrazvijeniji u ovim oblastima, i gde su restrikcije unutar samih destinacija bile nešto blaže nego u urbanim zonama.

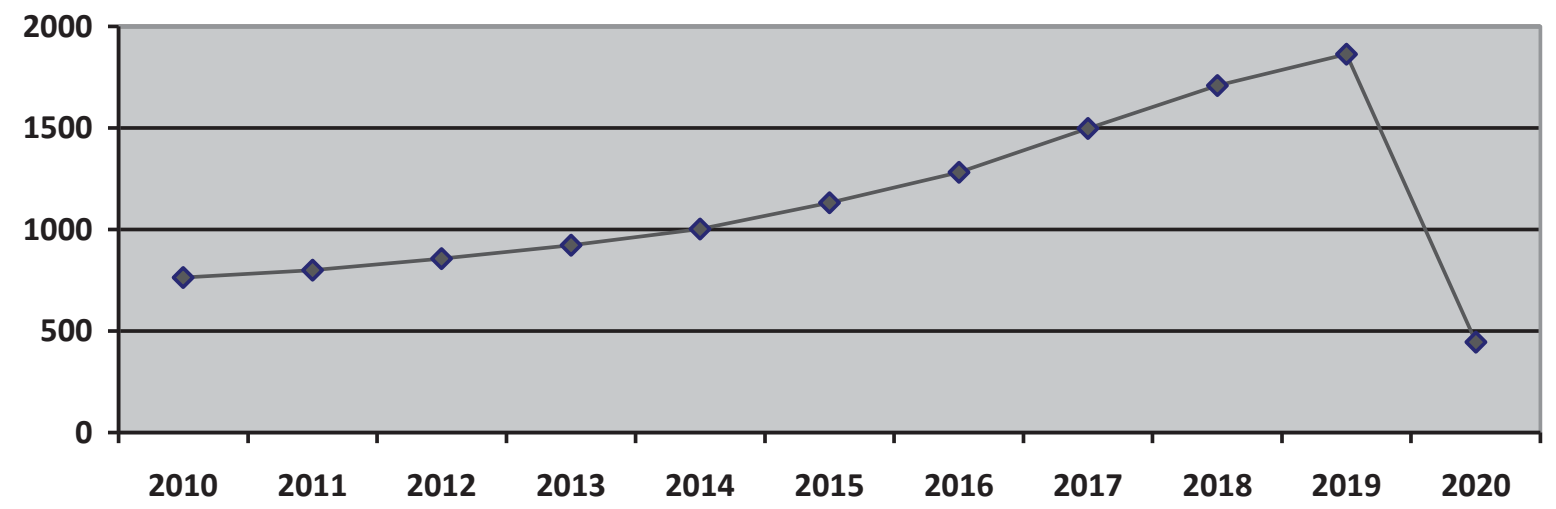

Grafikon 3 - Broj međunarodnih turističkih dolazaka na području Republike Srbije, u periodu 20102020.godina, u hiljadama

Graph 3 - Number of international tourist arrivals in the territory of the Republic of Serbia, in the period 2010-2020, in thousands

Izvor: Autori prema UNWTO 2021a, RZS, 2020 i RZS, 2021

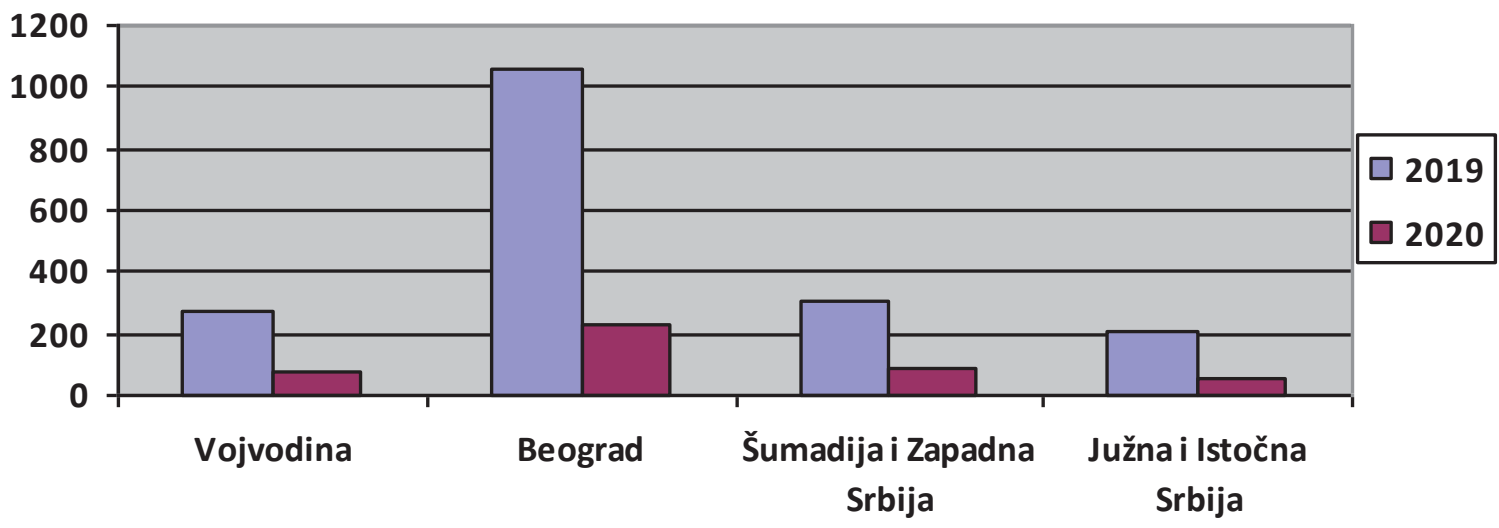

Grafikon 4 - Broj međunarodnih turističkih dolazaka tokom 2019. i 2020.godine, po regionima u Republici Srbiji, u hiljadama

Graph 4 - Number of international tourist arrivals during 2019 and 2020, by regions in the Republic of

Serbia, in thousands

Izvor: Autori prema RZS, 2020 i RZS, 2021

Ovakav pad međunarodnog turizma stvorio je brojne negativne ekonomske efekte po Republiku Srbiju. Preliminarne analize procenjuju da je direk- tan gubitak od međunarodnog turizma oko milijardu $€$, dok indirektan i indukovan iznose znatno više. Gubitak u drugim povezanim privrednim granama 
(poljoprivredi, saobraćaju, industriji) je svakako znatno veći, ali ga je teško kvantifikovati. Takođe, radna mesta u turizmu i povezanim granama su u velikom riziku. Država merama podsticaja obezbeđuje očuvanje najvećeg broja tih mesta, ali takva podrška ne može da bude rešenje na dugi rok.

Da bi se smanjio negativan efekat, mnoge destinacije su se okrenule razvoju domaćeg turizma, odnosno, svoju turističku ponudu su usmerile ka privlačenju domaćih turista, uz veliku podršku države, pre svega u vidu podsticaja putem vaučera. Pojedine destinacije (Stara planina, Divčibare, Sokobanja, Ribarska banja) su povećale ukupan broj turista tokom 2020.godine u odnosu na 2019. godinu (Vassileva et al, 2020), prevashodno zbog porasta broja domaćih turista, koji zbog zatvaranja granica nisu mogli da putuju izvan Republike Srbije, pa su svoje turističke potrebe zadovoljili u prethodno navedenim destinacijama.

\section{ZAKLJUČAK / CONCLUSION}

Pandemija COVID-19 je značajno uticala na ekonomiju mnogih zemalja. Posebno su bile pogođene uslužne delatnosti, kao i one koje su dominantno orjentisane na međunarodno tržište. Međunarodni turizam je tipičan primer negativnog ekonomskog efekta. Rezultati koji su ostvareni u prethodnoj godini pokazuju dosta zabrinjavajuće tendencije. Pad međunarodnog turizma od $73,9 \%$, procenjeni direktan gubitak od 1.300 milijardi \$, sa evidentno većim indirektnim, potvrđuje prethodno iznet stav. Slična situacija je i na području Republike Srbije, gde je tokom 2020.godine zaustavljen intenzivan razvoja međunarodnog turizma u drugoj deceniji XXI veka.

Ono što predstavlja još veći problem je nepredvidivost međunarodnog turizma u narednim godinama. Projekcije međunarodnog turizma se menjaju gotovo svakog meseca i svaka naredna je pesimističnija od prethodne. Strah koji postoji kod većine potencijalnih turista, nepoverenje u načine rešavanja pandemije ne daju optimizam u bliskoj budućnosti. Orjentacija na domaći turizam, kao kratkoročno prelazno rešenje, ne može u potpunosti da umanji negativne ekonomske efekte, kako na globalnom nivou, tako i na nivou Republike Srbije.

\section{LITERATURA / REFERENCES}

[1] Bošković, N. (2020). Održivi razvoj turističkih destinacija. Ekonomski fakultet. Kragujevac, 184 str.

[2] Đurović, S., Perović, A., Šiljak, V., Antonijević, S., Veselinović, J. Baćevac, S. (2020). Održivost razvoja sportskog turizma kao privredne grane: uticaj COVID-19, Ecologica, 27 (100), 699-706.
[3] Gössling, S., Scott, C. D., Hall, M. (2020). Pandemics, tourism and global change: A rapid assessment of COVID-19. Journal of Sustainable Tourism, 29 (1), 1-20.

[4] Kostić, M., Lakićević, M., Milićević, S. (2018). Sustainable tourism development of mountain destinations in Serbia, Economics of Agriculture, 65(2), 843-857.

[5] Lukinović, M. Jovanović, L. (2020). Uticaj pandemije COVID -19 na životnu sredinu, Ecologica, 27 (99), 376-382.

[6] Milenković, S., Bošković, N. (2014). Oblikovanje Kragujevca kao turističke destinacije, U: Maksimović, Lj., Stanišić, N. (red.). Stanje i perspektive ekonomskog razvoja grada Kragujevca. Kragujevac: Ekonomski fakultet, str. 119-129.

[7] NBS (2021). Platni bilans Republike Srbije 20072020, dostupno na https://nbs.rs/sr_RS/druginivo-navigacije/statistika/platni_bilans/ (pristup: 06.03.2021)

[8] Page, S., Connell, J. (2020). Tourism - a modern syunthesis. Cengage, Hampshire, 656 p.

[9] RZS (2020). Statistički godišnjak 2019, dostupno na https://publikacije.stat.gov.rs/G2020/Pdf/ G20202053.pdf (pristup: 12.03.2021)

[10] RZS (2021). Turistički promet decembar 2020, dostupno na https://publikacije.stat.gov.rs/ G2021/Pdf/G20211024.pdf (pristup: 12.03.2021)

[11] Stefanović V., Gligorijević, Ž. (2016). Ekonomika turizma. Prirodno-matematički fakultet, Niš, 365 str.

[12] Uğur, N.G., Akbıyık, A. (2020). Impacts of COVID19 on global tourism industry: A cross-regional comparison, Tourism Management Perspectives, 36, pp. 100744.

[13] UNWTO (2020). Global and regional tourism perferomance, dostupno na https://www.unwto.org/global-and-regionaltourism-performance (pristup: 01.02.2021)

[14] UNWTO (2021a). Global and regional tourism performance, dostupno na https://www.unwto.org/global-and-regionaltourism-performance (pristup: 04.02.2021)

[15] UNWTO (2021b). World Tourism Barometer, Vol.19, Iss. 1, 2021, dostupno na https://www.eunwto.org/doi/epdf/10.18111/wtobarometereng.2 021.19.1.1 (pristup: 09.03.2021)

[16] Vassileva, A., Simić, M., Stevanović, M. (2020). Implications of COVID-19 for international business, Ecologica, 27 (100), 589-596. 